\title{
Wild food plants of Qakh district of Azerbaijan, the Southeastern Caucasus: diversity and distribution pattern along an elevation gradient
}

\section{Aida Ibrahimova \\ Institute of Botany, Azerbaijan National Academy of Sciences, Badamdar 40, Baku, AZ1004, Azerbaijan}

Abstract: Environment can not exist without plants. Historically, plants have often been selected for different uses, as medicinal, food, ornamental and others. Plants are one of the main sources of food for life. Much of the food plants exist in nature as wild. Currently the depletion of natural resources is observed around the world. Considering these, it is important to study their location, resources and knowledge of their traditional use. Qakh is a historical district of the Azerbaijan, located in the north-west part of the country and on the south macroslope of the western part of the Great Caucasus. The region is one of the least studied areas of the country in terms of plant diversity. The checklist of wild food plants of the region has not been prepared, although the useful plants have been studied by a number of scientists. Generally, 323 wild food plants (vascular) were recorded in the region across 72 families and 211 genera, with by far the largest family being Asteraceae (35 plant species), followed by Rosaceae, Apiaceae, Fabaceae, Brassicaceae, Lamiaceae, Malvaceae and Polygonaceae. Total number of species include 29 tree species, 18 shrubs, 2 subshrubs, 1 climber, 69 annual, 27 biennial and 177 perennial herbs. It was recorded one endemic species of Azerbaijan (Rubus buschii Grossh. ex Sinkova), 35 endemics of Caucasus, and 25 species listed in the Red Book of the Republic of Azerbaijan. Most of the food plants are distributed in the northern and northeas-tern parts of the study area (263 species). The southern part has less numbers (55 species) than middle part (147 species) of the region. Besides, 52 species are found all over the area. In general, the high plant species richness in the area is found in lower and middle mountain zone between $600 \mathrm{~m}$ and $1700 \mathrm{~m}$. Cluster analysis based on presence/absence of food plants of the area along an altitudinal gradient determinate two main cluster groups, where the first group consists of plants of the alpine zone and the second group combines the other zones.

Accepted for publication: 15 Novermber 2019

'E-mail: aida_dadashova@yahoo.com

\author{
Key Words: plant use, floristic analysis, statistical \\ analysis, threats
}

\section{INTRODUCTION}

The existence of plants is very important for the life on the Earth. Food plants are irreplaceable nutrients and energy resources for humans, and also many food combinations are processed from plant sources. Since ancient many food plants have been used as food. A large part of the food plants have been studied in detail, but people are still discovering different uses. Generally, plant-based foods are known as legumes, fruits, grains, vegetables, seeds and nuts. $80 \%$ of the food derived from world's plants come from 17 plant families [Willis, 2017].

The Caucasus Ecoregion is located between the Black and Caspian seas. The Caucasus Mountains system include the Great Caucasus (north part) and the Lesser Caucasus Mountain Ranges (south part), locate at the intersection of Europe and Asia. The Caucasus is listed as one of eight global centers for the domestication of plants, and many food plants having their origins from the South Caucasus. The region contains an amazing variety of vascular plants, with about 6300 described species [Bussmann et al., 2017]. Barley, wheat, grapes, rye, peas, pears, pomegranates, and many other species can be found growing wild and are the ancestors or close relatives of economically important plants grown present-day.

Azerbaijan occupies the southeastern part of the Caucasus. The Great and Lesser Caucasus Mountains cover more than a half of the territory of the country and its altitude range between $30 \mathrm{~m}$ below sea level to $4466 \mathrm{~m}$ above sea level. The temperature varies depending on the relief [Museyibov, 1998]. The country has a rich and varied plant cover, consisting of a large number of useful and economically important plants. The flora of Azerbaijan consists of about 5000 plant species, belonging to 1142 genera of 186 families [The flora of Azerbaijan, 1950-1961; Asgarov, 2011], including 200 endemics of Azerbaijan and 950 endemics of the Caucasus [Red book of Azerbaijan, 2013, Red list of the endemic plants of the Caucasus, 2014]. M.A. Qasimov et al. [Qasimov et al., 2010]. are recorded 746 wild plants as vegetable for the flora of Azerbaijan. In generally, 
the flora of the country is represented in twenty botanygeographical regions. Qakh is a historical district of the country, located is the north-west part of Azerbaijan and on the south macro-slope of the western part of the Great Caucasus.

Approximately $30 \%$ of the total area of the region territory are occupied by forests. The main purpose of the study is the compilation of a checklist of wild food plants of Qakh district, also definition of their food properties and distribution patterns.

\section{MATERIAL AND METHODS}

Study area. The Caucasus is situated between the Black and Caspian seas, between latitudes $39^{\circ}-47^{\circ} \mathrm{N}$ and longitudes $40^{\circ}-50^{\circ} \mathrm{E}$. The southwestern Caucasus includes counties - Georgia, Armenia and Azerbaijan and is characterized by a very mild and humid climate. The Republic of Azerbaijan is located in the southeastern part of the Caucasus at the crossroads of eastern Europe and south-west Asia. It is the largest country in the southern Caucasus $\left(86.600 \mathrm{~km}^{2}\right)$. Nine out of thirteen main climate types are represented in the country [Museyibov, 1998].

The investigations were carried out in Qakh district (Fig. 1), situated in the north-west of Azerbaijan, in 2012-2019. Nearly $40 \%$ of region is mountainous. The northern and northeastern parts of the region belong to the Western Great Caucasus, central part to the AlazanAyrichay valley, and the southern part to Bozgyr plateau including to 20 botanical-geographical regions of Azerbaijan.

The study area is divided into six altitude zones: 1) lowland and foothills (up to $400 \mathrm{~m}$ a.s.1.); 2) lower mountain zone $(500-800) ; 3)$ middle mountain zone (800-1700); 4) upper mountain zone (1700-2000); 5) subalpine zone (2200-2400); 6) alpine zone (24003200) [Museyibov, 1998].

Floristic composition and plant uses. Study of the plant cover was carried out by the route and sampling, generally accepted methods in geobotany [Field geobotany, 1960]. The plant checklist was prepared based on data collected during the field trips in the study area and literature resources [The flora of Azerbaijan, 1950-1961; Ali-zade et al., 2019].

Accepted scientific names and synonyms were determined according to the Flora of Azerbaijan, then verifi-ed and updated according to other sources [The flora of Azerbaijan, 1950-1961, Kew Plant List home page, World Flora Online (WFO) home page]. Herbarium vouchers are stored in the Herbarium Foundation

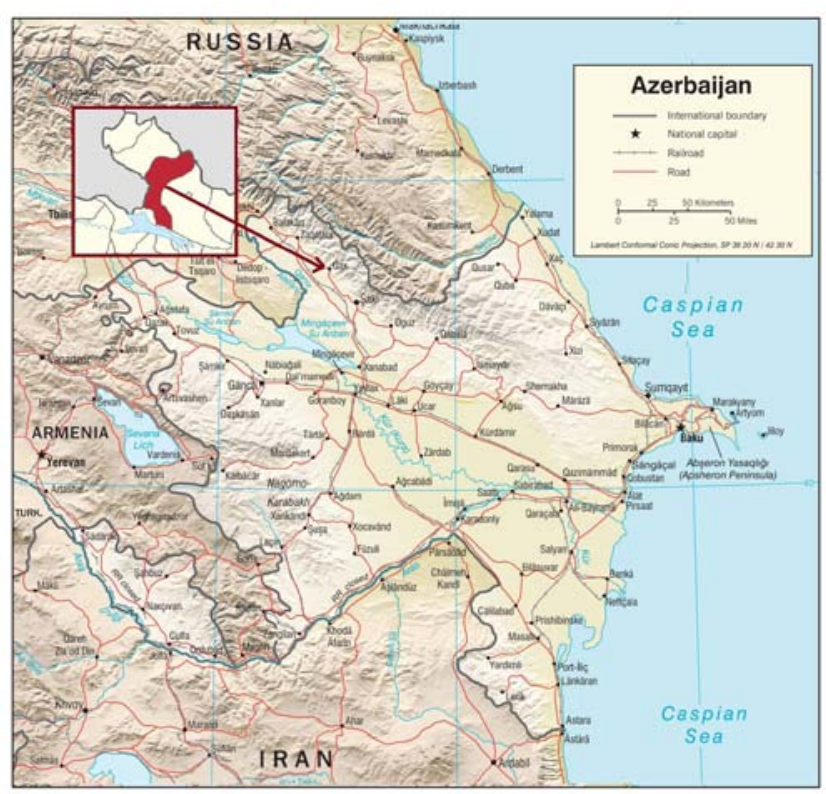

Figure 1. Location of the Qakh district in the northwestern part of Azerbaijan Republic.

(BAK) of the Institute of Botany of ANAS.

Data about the uses of food plants was obtained based on interviews and literature resources [The flora of Azerbaijan, 1950-1961, Qasimov, 2010, Bussmann et al., 2017]. Interviews were conducted during field surveys with people living in the area. However, most participants were over 50 years old, because only very few younger people has information about food plants. Statistical analysis. The food plant diversity of the Qakh district has been analyzed using Venn diagrams [Venn, 1880], between all botanical-geographical regions. The $\mathrm{R}$ programming was used in the statistical analysis and mapping of the region along on altitude gradient. The distribution of food plant species richness pattern was analyzed using the simple linear regression model [Mcdonald, 2014] along an altitudinal gradient. Algorithm UPGMA based on the presence or absence data of species along the altitude zones were implemented. Clusters are formed based on Jaccard similarity index $\left(\mathrm{K}_{\mathrm{J}}\right)$ :

$$
K_{J}=\frac{c}{a+b-c}
$$

where, a - represents the total number of members in A site; $b$ - represents the total number of members in $B$ site; $\mathrm{c}$ - represents the total number of similary members in both sites.

An altitudinal map (elevation a.s.l., m) of the study area was created according the highest-resolution topo- 
graphic data generated from Shuttle Radar Topography Mission (SRTM), extracting to the R, generally using "raster" and "maptools" packages. The altitude variables ("alt") were calculated at the spatial resolutions - 30 seconds $(0.93 \times 0.93=0.86 \mathrm{~km} 2$ at the equator $)$ [WorldClim - Global Climate Data page]. GPS coordinates of plant species were recorded with Garmin Etrex 10.

\section{RESULTS AND DISCUSSION}

Floristic and plant uses analysis of the data. As a result of research, 323 wild food plants (vascular) were recorded in Qakh district across 72 families and 211 genera, with by far the largest family being Asteraceae with 35 species, followed by Rosaceae-31, Apiaceae -28, Fabaceae-22, Brassicaceae-17, Lamiaceae-14, Malvaceae-13, Polygonaceae-11, while sixty four families represented by one to ten species (Fig. 2). The study territory consists of 29 tree species, 18 shrubs, 2 subshrubs, 1 climber, 69 annual, 27 biennial and 177 perennial herbs.

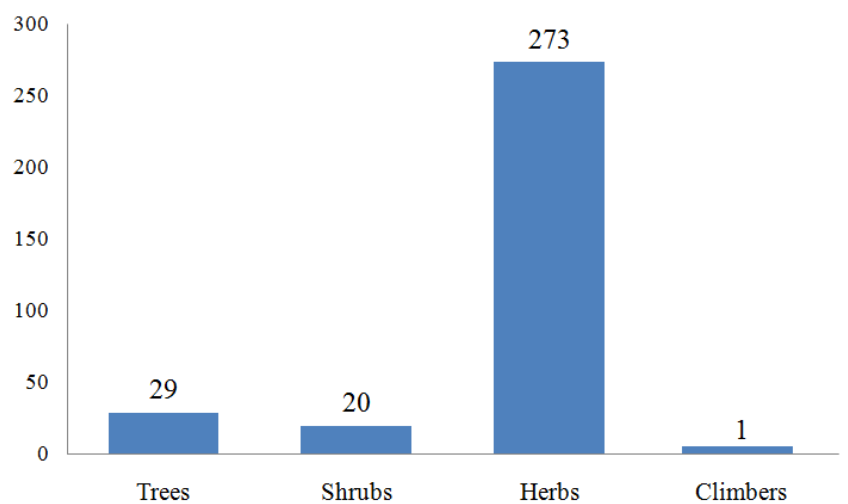

Figure 2. Frequency of wild food plant taxa arranged by life forms.

Most of the food plants are distributed in the northern and northeastern parts of the in the study area (the Western Great Caucasus botanical-geography region). This is due to the fact that about $80 \%$ of the total flora of the study area is distributed in this territory; also the area has the favorable natural and climatic conditions for the plants. Regardless of the number of species, valuable food plants are common in whole of the study area. Besides, 52 species are found all over the area (Fig. 3).

Analyzing the endemism of the food plant diversity of the Qakh district, it was recorded one endemic species of Azerbaijan (Rubus buschii Grossh. ex Sinkova), 35 endemic of Caucasus. Out of total number species recorded in the Red Book of the Republic of Azerbaijan 25 species are found in the district [2013].

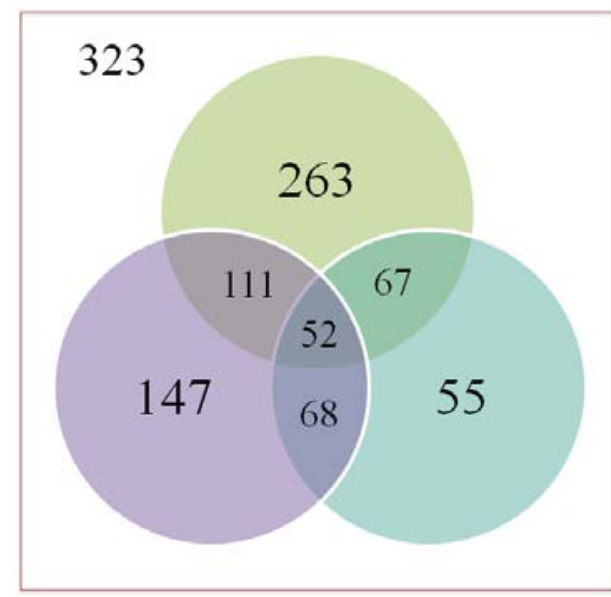

Figure 3. Distribution of food plants shared among botanical-geographical regions in the Qakh district:

Qakh region; Western of the Great Caucasus;

Alazan-Ayrichay valley; Bozgyr plateau

As a result of interviews have been revealed that some plants (Allium ursinum L., Rhus coriaria L., Stellaria media (L.) Vill., Chenopodium album L., Portulaca oleracea L., Cornus mas L., Castanea sativa Mill., Malva sylvestris L., Punica granatum L., Fragaria vesca L., Fragaria viridis (Duch.) Weston, Rubus anatolicus (Focke) Focke ex Hausskn., Urtica dioica L. and etc.) are more traditionally common used food plants by people in the area (Tab., Fig. 4). Some of these are often used in the preparation of national meals.

As a result of the analysis of food plants it became clear that, 47 species have only food properties [The flora of Azerbaijan, 1950-1961; Qasimov, 2010; Mehdiyeva, 2011; Ibadullayeva, 2013; Bussmann et al., 2017; Alizade et al., 2019]. Other 275 plants species have medicinal, ornamental, melliferous, dye, feed and different technical useful properties. Of these, 190 plant species have medicinal properties.

Statistical analysis of the data. As a result of interviews it has been revealed that the reserves of Allium ursinum, Castanea sativa, Punica granatum and Rhus coriaria plant species are widely collected and used in the district by people, from total number of rare species of Azerbaijan in the study area [Red Book of Azerbaijan, 2013]. This factor crucially affects the spread of $A$. ursinum, $C$. sativa and $R$. coraira leading to the decline of the number of individuals. During field surveys 34 locations of these species were recorded. First we created a map of study area along altitudinal gradient, and then the distribution of these species is indicated on the map 


\section{PLANT \& FUNGAL RESEARCH}

Table. Traditionally common used wild food plants by people in Qakh district.

\begin{tabular}{|c|c|c|c|c|c|}
\hline Latin name & $\begin{array}{c}\text { Common } \\
\text { name }\end{array}$ & "Use description & Part used & Life form & Location \\
\hline \multicolumn{6}{|l|}{ Alliaceae } \\
\hline Allium ursinum & ay1 soğan1 & salad, vegetable, soup & flowers, leaves, bulb & perennial & 2,3 \\
\hline \multicolumn{6}{|l|}{ Corylaceae } \\
\hline Corylus avellana & adi findiq & $\begin{array}{l}\text { fresh or dried eat, cakes, } \\
\text { biscuits }\end{array}$ & fruits & tree & 2,3 \\
\hline \multicolumn{6}{|l|}{ Anacardiaceae } \\
\hline Rhus coriaria & aş1 sumağ1 & oil, spices & fruits & shrub & $1,2,3$ \\
\hline \multicolumn{6}{|l|}{ Amaranthaceae } \\
\hline $\begin{array}{l}\text { Amaranthus } \\
\text { retroflexus }\end{array}$ & $\begin{array}{l}\text { qara } \\
\text { pəncər } \\
\text { (qara tərə) }\end{array}$ & $\begin{array}{l}\text { as a spinach substitute, } \\
\text { salads, added to maize } \\
\text { meal }\end{array}$ & $\begin{array}{l}\text { the young leaves and } \\
\text { shoots, seeds }\end{array}$ & annual & $1,2,3$ \\
\hline \multicolumn{6}{|l|}{ Caryophyllaceae } \\
\hline Stellaria media & cincilim & $\begin{array}{l}\text { in national meals, salat, } \\
\text { sprouts, sandwiches }\end{array}$ & $\begin{array}{l}\text { flower, stem, leaves, } \\
\text { seed }\end{array}$ & annual & $1,2,3$ \\
\hline \multicolumn{6}{|l|}{ Chenopodiaceae } \\
\hline Chenopodium album & ağımtıl tərə & $\begin{array}{l}\text { as a spinach, like } \\
\text { broccoli }\end{array}$ & $\begin{array}{l}\text { the young leaves and } \\
\text { shoots, tops of mature } \\
\text { plants, the flowers } \\
\text { and sprouted seed }\end{array}$ & annual & 2,3 \\
\hline \multicolumn{6}{|l|}{ Cornaceae } \\
\hline Cornus mas & adi zoğal & marinade, jam & fresh and dried fruits & tree & $1,2,3$ \\
\hline \multicolumn{6}{|l|}{ Fagaceae } \\
\hline Castanea sativa & adi şabalıd & $\begin{array}{l}\text { in national meals, eating } \\
\text { fresh fruits }\end{array}$ & fruits & tree & 3 \\
\hline \multicolumn{6}{|l|}{ Lamiaceae } \\
\hline Mentha longifolia & $\begin{array}{l}\text { uzunyar- } \\
\text { paq yarp1z }\end{array}$ & tea, conditery & leaves & perennial & $1,2,3$ \\
\hline \multicolumn{6}{|l|}{ Malvaceae } \\
\hline Malva sylvestris & $\begin{array}{l}\text { meşə } \\
\text { əməkömə- } \\
\text { ci, balba }\end{array}$ & in national meals, salat & leaves, stems & annual & $1,2,3$ \\
\hline \multicolumn{6}{|l|}{ Portulacaceae } \\
\hline Portulaca oleracea & $\begin{array}{l}\text { bağça } \\
\text { pərpərən }\end{array}$ & salad, marinade & $\begin{array}{l}\text { leaves, stems, flowers } \\
\text { and seeds }\end{array}$ & annual & 1,2 \\
\hline \multicolumn{6}{|l|}{ Punicaceae } \\
\hline Punica granatum & adi nar & juice, jam & fruits & tree & $1,2,3$ \\
\hline \multicolumn{6}{|l|}{ Rosceae } \\
\hline Crataegus pentagyna & $\begin{array}{l}\text { beşyuvalı } \\
\text { yemişan }\end{array}$ & juice & fruits & tree & 2,3 \\
\hline Fragaria vesca & $\begin{array}{l}\text { meşə } \\
\text { çiyələyi }\end{array}$ & juice, jam & fruits & perennial & 2,3 \\
\hline Fragaria viridis & $\begin{array}{l}\text { göy } \\
\text { çiyələk }\end{array}$ & juice, jam & fruits & perennial & 2,3 \\
\hline Rubus anatolicus & $\begin{array}{l}\text { anatoli } \\
\text { böyürtkanı }\end{array}$ & juice, jam & fruits & shrub & 2,3 \\
\hline \multicolumn{6}{|l|}{ Urticaceae } \\
\hline Urtica dioica & $\begin{array}{l}\text { ikievli } \\
\text { gicitkan }\end{array}$ & soups, in national meals & leaves & perennial & $1,2,3$ \\
\hline \multicolumn{6}{|l|}{ Vitaceae } \\
\hline Vitis sylvestris & $\begin{array}{l}\text { meşə } \\
\text { üzümü }\end{array}$ & $\begin{array}{l}\text { in national meals, juice, } \\
\text { jam, cakes, biscuits }\end{array}$ & young leaves, fruits & climber & $1,2,3$ \\
\hline
\end{tabular}

Note: 1 - Bozgyr plateau, 2 - Alazan-Ayrichay valley, 3 - Western part of the Great Caucasus botanical-geographical regions. 


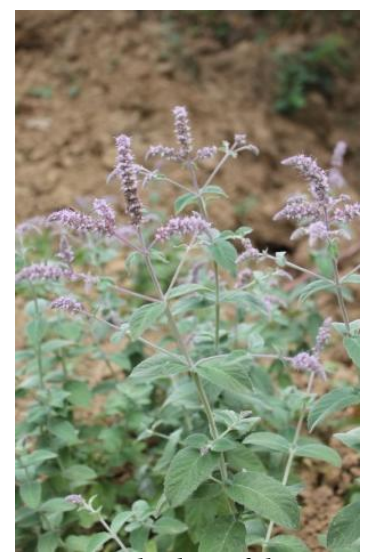

Mentha longifolia

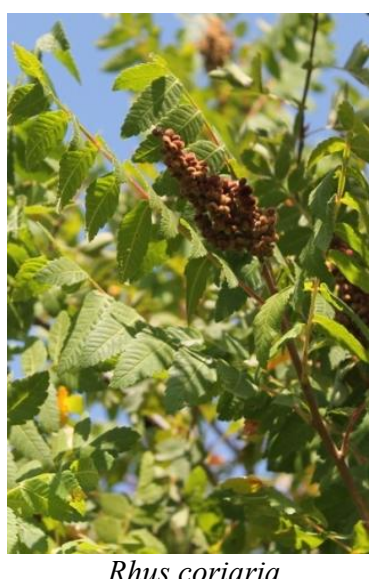

Rhus coriaria

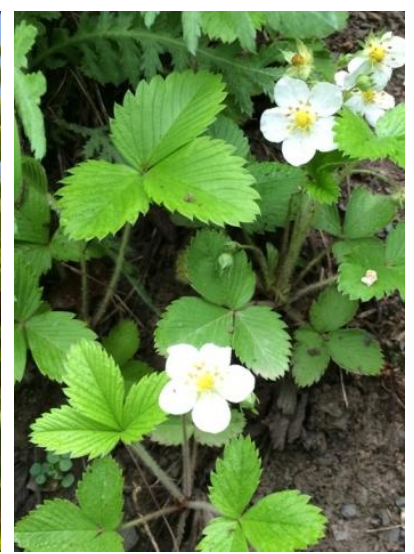

Fragaria vesca

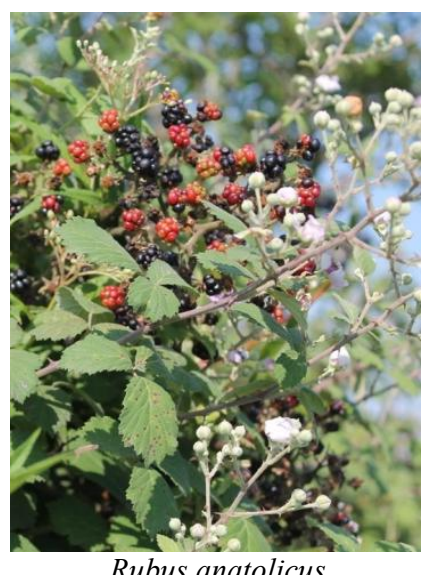

Rubus anatolicus

Figure 4. Wild food plants of Qakh district.

(Fig. 5). The map shows that $C$. sativa is mainly found in higher altitude zones (800-1700 m a.s.1.). However, $P$. granatum is widely distributed in the lowlands (up to $300-350 \mathrm{~m}$ a.s.1.). A. ursinum generally is distributed from the lowland to higher mountain zone, but mostly found in large numbers in lowland and lower mountain zone.

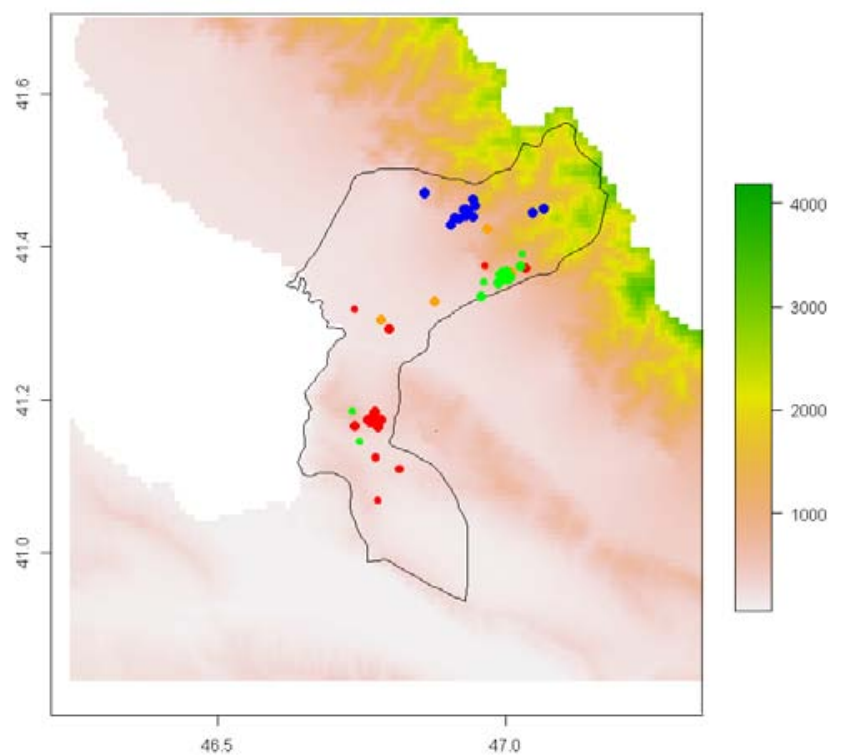

Figure 5. Distribution of four rare food plant species [Red Book of Azerbaijan, 2013] along an altitude gradient in Qakh district: the species are represented as circles - Allium ursinum (orange), Castanea sativa (blue), Punica granatum (red), Rhus coriaria (green).

Wild food plant species are distributed across all elevation areas throughout Qakh district. The patterns of food plant species richness along elevation gradient is shown in figure 6 . There is a significant decrease in total species richness along altitude from $2000 \mathrm{~m}$ to $3200 \mathrm{~m}$ in alpine and subalpine zones. From the total number of the species, only two species (Vaccinium myrtillus L., Carduus crispus L.) are found in subalpine and alpine areas. Overall, 11 plant species of plants belonging to nine genera of nine families are distributed in the high altitudinal zones. In general, the high plant species richness in the area is found in lower and middle mountain zone between $600 \mathrm{~m}$ and $1700 \mathrm{~m}$, with maximum value observed at $600-900 \mathrm{~m}$. This can be explained by the fact that, most of the wild food plants, 172 plant species (53.25 percent of the total species) are distributed in the lower and middle mountain zone. The main reason for the decline of species richness over high elevation is the decrease of the total number of species in the region. The distribution of most of the food plants in the lower and middle mountain zones increases the possibility of their use by humans.

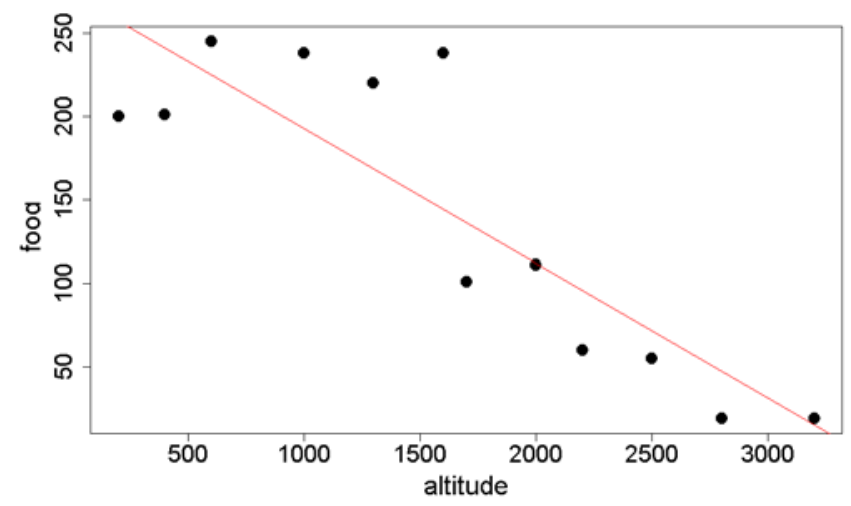

Figure 6. Simple linear regression of variations of total species richness of food plants along an altitudinal gradient $\left(\mathrm{R}^{2}=0.7236, \mathrm{p}=0.0002775, \mathrm{y}=-0,080\right.$, $\mathrm{x}+273,2)$ 
Cluster analysis based on presence/absence of food plants of the area along an altitudinal gradient determinate two main cluster groups. The first group consists of the alpine zone, while the second group is divided into different subgroups with other altitudinal zones. The high similarity coefficients $\left(\mathrm{K}_{\mathrm{J}}\right.$, Jaccard $)$ were determined for the lower and middle mountain zones -0.7636 . Moreover, the lowland and lower mountain zone have -0.7587 , the lowland and the middle mountain zone -0.5863 high similarity coefficients. The higher mountain and subalpine zones are grouped together under the subgroup which indicates that they have similar food plant diversity (Fig. 7).

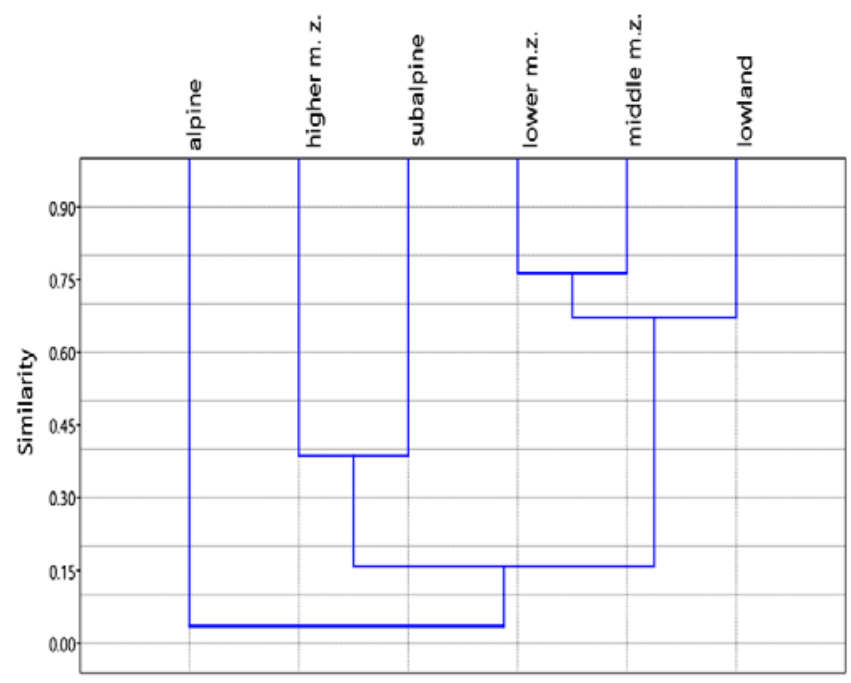

Figure 7. Dendrogram of the food plant diversity along on altitude, formed according Jaccard similarity index, UPGMA algorithm.

Threatened species. Allium ursinum - the bear's garlic (known also as buckrams, ramsons, wild garlic, wood garlic, broad-leaved garlic or bear leek) widespread distributed in Europe and Asia. In Azerbaijan, the species can be found only in the north-western part of Azerbaijan, also in Qakh district. It is a rare species of Azerbaijan, which is included the Red Book of Azerbaijan (2013) with National IUCN status Vulnerable (VU) [Dadashova et al., 2017].

All parts of the plant are edible, but leaves are the mostly used part. In the study area mass collection of this species was observed. Basically, the plant is harvested before flowering. This prevents the reproduction of this species by seeds. Currently planting of the species is observed in the region.

Rhus coriaria - known as scilian sumac, tanner's sumach, elm-leaved sumach can be found in the Western
Great Caucasus and Bozgyr plateau botanical-regions in the study area. It is a rare species of Azerbaijan, which included in the Red Book of Azerbaijan (2013) with National IUCN status - Vulnerable (VU).

The fruits of the plant has a sour taste, it is a popular spice in the East, also in Azerbaijan as dried and crushed. The fruits of the species are also collected by people. However, this factor does not pose a threat in reducing its number. The main factor of decrease is the collection of trees as firewood. Individuals of trees in the lower mountain zone in massive numbers are collected by people, due to the fact that these areas have easier accessibility.

\section{CONCLUSION}

Finally, it is interesting to note that some wild food plants are distributed in large areas in Qakh district that can be used for healthy living. The paper presents originally prepared checklist of wild food plant species of the district, and analyzed at the taxonomic level and distribution along an altitudinal gradient. In future studies, it is aimed to research a widely distributed areas of wild food plants and their use prospects. It also specify that two red list species of $A$. ursinum and $R$. coriaria affected with a negative factor such as collecting by human activity, than $C$. sativa and $P$. granatum. $C$. sativa tree species have been widely cultivated by humans since ancient times in the area. P. granatum is also commonly encountered in the culture. Recently, A. ursinum has been also cultivated in the gardens (private) because of the species is widely in use. At a time when there is a reduction in the risk of natural resources it is important to investigate natural food sources.

\section{REFERENCES}

Alizade V.M., Mehdiyeva N.P., Karimov V.N., Ibrahimova A.G. (2019) Plants of the Greater Caucasus (Editor Thomas Borsch). Baku: Red N Line, $352 \mathrm{p}$.

Asgarov A.M. (2011) Conspectus of the flora of Azerbaijan. Additions and changes (1961-2009). Baku: Letterpress, 204 p. (In Azerbaijani)

Bussmann R.W. (editor) (2017) Ethnobotany of the Caucasus. Springer, 745 p.

Dadashova A.G., Alizade V.M., Kerimov V.N. (2017) Ontogenetic structure and current state of the ceonopopulation of rare species Allium ursinum L. in he north-west part of Azerbaijan. Proceedings of the Institute of Botany, ANAS, XXXVII: 4-7.

Field geobotany (1960) Ed.: E.M. Lavrenko, A.A. Ko- 
rchagina. Moscow: AN SSSR, 2: 83-86 pp. (In Russian)

Ibadullayeva S.J., Alekperov R. (2013) Medicinal herbs (ethnobotany and phytotherapy). Baku: Education, 331 p. (In Azerbaijani)

Kew Plant List home page: Available from: https:// www.theplantlist.org

Mcdonald J.H. (2014) Handbook of Biological Statistics (third edition). USA: Sparky house publishing, $299 \mathrm{p}$.

Mehdiyeva N.P. (2011) Biodiversity of medicinal flora of Azerbaijan. Baku: Letterpress, 188 p. (In Azerbaijani)

Museyibov MA (1998) Physical Geography of Azerbaijan. Baku: Education, 399 p.

Qasimov M.A., Xalilov V.S., Qasimova T.A. (2010) Wildgrowing vegetable plants of Azerbaijan and perspectives of their use. Transactions of Society of Azerbaijan Botanists, 1: 371-396. (In Azerbaijani)

Red Book of Azerbaijan (2013) Rare and endangered plant and fungi species. Second edition, Baku:xxx $676 \mathrm{p}$.

Red list of the endemic plants of the Caucasus (Armenia, Azerbaijan, Georgia, Iran, Russia and Turkey) (2014). Editors - James Soloman, Tatyana Shulkina and George E. Schatz, $451 \mathrm{p}$.

The flora of Azerbaijan (1950-1961) Baku: AN Azerb. SSR, I-VIII. (In Russian)

Venn J. (1880) On the diagrammatic and mechanical representation of propositions and reasonings. London, Edinburgh: Dublin Philosophical Magazine and Journal of Science, 5.10 (59): 1-18.

Willis K.J. (ed.) (2017) State of the World's Plants 2017. Report, Royal Botanic Gardens Kew, 96 p.

World Flora Online (WFO) home page: https://www. worldfloraonline.org.

WorldClim - Global Climate Data page: https://www. worldclim.org/version1.

\section{Azərbaycanın Qax rayonunun yabanı qida bitkiləri, Qafqazın cənub-şərqi: növmüxtəlifliyi və hündürlükdən asılı olaraq yayılması}

\section{Aida Q. İbrahimova \\ AMEA Botanika Institutu, Badamdar şossesi 40, Bakl, AZ1004, Azorbaycan}

Otraf mühit bitkilərsiz mövcud ola bilməz. Tarixən bitkilər tez-tez dərman, qida, bəzək və digərləri kimi müxtəlif məqsədlər üçün seçilmişdir. Bitkilər həyat üçün əsas qida mənbələrindən biridir. Yem bitkilərinin bir çoxu təbiətdə yabanı olaraq mövcuddur. Hazırda dünyada təbii ehtiyatların tükənməsi müşahidə olunur. Bunları nəzərə alaraq, yabanı qida bitki növlərinin yayılma areallarının, və ənənəvi istifadəsi barədə məlumatları öyrənmək vacib və aktual hesab edilir. Qax rayonu Azərbaycanın tarixi bölgəsi olmaqla, ölkənin şimal-qərb hissəsində və Böyük Qafqazın qərb hissəsinin cənub yamacında yerləşir. Hal-hazırki dövrə qədər faydalı bitki növləri bir sira alimlər tərəfindən araşdırılmasına baxmayaraq, Qax rayonunun yabanı qida bitkilərinin ümumi siyahı hazırlanmamışdır. Tədqiqat işləri 2012-2019-cu illərdə aparılmışdır. Burada 72 fəsilə və 211 cinsə aid 323 yabanı qida bitkiləri qeydə alınmışdır. Növ sayı baxımından ən iri fəsilə Asteraceae (35 növ), daha sonra gələn fəsilələr Rosaceae, Apiaceae, Fabaceae, Brassicaceae, Lamiaceae, Malvaceae və Polygonaceae. Bunlardan, 29 növü ağac, 18 kol, 2 yarımkol, 1 lian, 69 birillik, 27 ikiillik və 175 çoxillik bitki növləridir. Qida bitkilərinin əksəriyyəti tədqiq olunan ərazinin şimal və şimal-şərq hissələrində daha çox rast yayılmışdır. Bundan əlavə, 52 qida bitki bütün ərazi boyunca yayılmışdır. Tədqiqat ərazisində 1 Azərbaycan endemi (Rubus buschii Grossh. Ex Sinkova), 35 Qafqazın endemi qeyd edilmişdir, 25 növ isə Azərbaycan Respublikasının Qırmızı Kitabına daxil edilmişdir. Qida bitki növləri yüksəklikdən asılı olaraq statistik təhlil edilmişdir və müəyyən edilmişdir ki, ən zəngin aşağı dağ qurşağından orta dağ qurşağına kimi $600 \mathrm{~m}$ - dən $1700 \mathrm{~m}$ arasında olan ərazilər növ müxtəlifliyi ilə daha da zəngindir. Bitki növlərinin ərazidə mövcud olub /olmamasına əsaslanan klaster təhlili nəticəsində 2 əsas klaster qrupu yaranmışdır.

Açar sözlor: bitkidən istifado, floristik təhlil, statistik tahlil, tahlükalar

\section{Дикорастущие пищевые растения Кахского районаАзербайджана, юго-восточный часть Кавказа: видовое разнообразие и в зависимости от градиента высоты}

\section{Аида К. Ибрагимова \\ Институт Ботаники НАНА, Бадамдар 40, Баку, AZ1004,Азербайджан}

Окружающая среда не могут существовать без растений. С древних времен растения часто отбирались для различных целей, таких как лекарственные, пищевые, декоративные и другие. Растения являются одним из основных источников пищи для жизни. Большая часть пищевых растений присутствует в естественной природе как дикая. В настоящее вре- 
мя наблюдается истощение природных ресурсов по всему миру. Учитывая это, важно и актуально изучить их местоположение, ресурсы и знания об их традиционном использовании. Кахский район находится на южном макросклоне западной части Большого Кавказа и является историческим регионом Азербайджана, расположенным в северо-западной части страны. Не смотря на то, что полезные растения района в свое время комплексно исследовались рядом ученых, список его дикорастущих пищевых растений до настоящего времени оставался не изученным. Нашими исследованиями зарегистрировано 323 пищевых растения, относящихся к 72 семействам и 211 родам. Наибольшим числом представителей характеризуется семейство Asteraceae, за которым следуют Rosaceae, Apiaceae, Fabaceae, Brassicaceae, Lamiaceae, Malvaceaе и Polygonaceae. Из общего числа выявленных видов 29 - деревья, 18 - кустарники, 2 полукустарника, 1 лиана , 69 - однолетники, 27- двухлетники и 175 многолетние травы. 52 вида пищевых растений распространено по всей территории области исследования. Большинство же сосредоточено в северной и северо-восточной частях Кахского района. В ходе исследований зарегистрирован один эндемик Азербайджана (Rubus buschii Grossh. Ex Sinkova), тридцать пять эндемиков Кавказа и двадцать пять редких и находящихся под угрозой исчезновения видов, занесенных в Красную книгу Азербайджанской Республики. Установлено, что нижний и средний горные пояса (от 600 до 1700 м над ур.м.) характеризуются высоким видовым разнообразием пищевых растений. Проведенный клястерный анализ, основанный на наличии / отсутствии кормовых растений района вдоль высотного градиента, определяет 2 основные кластерные группы.

Ключевье слова: использование растений, флористический анализ, статистический анализ, угрозы 